\title{
Wajah Ganda Agama: Integrasi, Konflik dan Rekonsiliasi
}

\author{
Tedi Kholiludin ${ }^{1}$ \\ Dosen Pascasarjana \\ Universitas Wahid Hasyim Semarang
}

\begin{abstract}
Abstrak
Asumsi sekularisme bahwa peran agama akan meredup pasca Pencerahan, nyata tidak terbukti. Dugaan akan tergerusnya agama di ruang publik, tak terwujud. Meski ada sekularisasi di masyarakat, tapi proses itu tidak berimbas pada kesadaran individu. Agama masih menjadi modal sosial dan memberikan pengaruh terhadap pergumulan masyarakat modern. Dalam bentuknya yang paling militan hingga yang halus kita merasakan bagaimana pengaruh dari Konfusianisme dan Taoisme di Cina dan Taiwan, Kristen Kharismatik serta Pentakostalisme di Afrika Selatan dan India, Kristen Ortodoks di Rusia, Islam di Indonesia serta spirit kapitalisme di Eropa Timur. Agama disini, menjadi sebentuk the hidden form of capital atau modal yang tersembunyi. ${ }^{2}$ Di lain wajah, sentimen agama, juga tak jarang menimbulkan banyak pertikaian. Konflik antar umat beragama semakin banyak kita temukan. Inilah era dimana counter terhadap sekularisasi justru semakin menguat. Agama selalu menghadirkan wajah ganda yang ambivalen, menjadi perekat dan sumber integrasi di satu sisi, tapi juga menjadi pemisah dan sumber konfilik di sisi lain. Bagaimana masyarakat yang tidak saling mengenal satu dengan lain, berasal dari berbagai belahan dunia bisa terbangun sentimennya karena agama. Juga sebaliknya, bagaimana ikatan-ikatan persaudaraan menjadi pudar karena berbeda agama atau pemahaman keagamaan.
\end{abstract}

Kata kunci: Agama, Integrasi, Konflik dan Rekonsiliasi

\begin{abstract}
The assumption of secularism that the role of religion will diminish after the Enlightenment is not proven. Allegations of religious erosion in the public sphere are unfulfilled. Although there is secularization in society, but the process does not affect individual consciousness. Religion is still a social capital and gives effect to the struggle of modern society. In its most militant to subtle form we feel the influence of Confucianism and Taoism in China and Taiwan, Christian Charismatics and Pentecostalism in South Africa and India, Orthodox Christianity in Russia, Islam in Indonesia and the spirit of capitalism in Eastern Europe. Here, Religion is being a form of hidden form of capital or hidden capital. On the other face, religious sentiments, also not infrequently cause a lot of disputes. Conflict among religious people more and more we find. This is an era where the counter to secularization is actually getting stronger. Religion always presents an ambivalent double face, a glue and source of integration on the one hand, but also a separator and a source of confidence on the other. How people who do not know each other, coming from different parts of the world can be awakened by religious sentiment. On the contrary, how fraternal bonds fade due to different religions or religious understanding.
\end{abstract}

Keyword: Religion, Integration, Conflict and Reconciliation

${ }^{1}$ Staf Pengajar Universitas Wahid Hasyim Semarang. Sekretaris Pengurus Wilayah Lakpesdam NU Jawa Tengah dan Ketua Yayasan Lembaga Studi Sosial dan Agama.

${ }^{2}$ Peter L. Berger, and Gordon Redding (ed), The Hidden Form of Capital: Spiritual Inf luences in Societal Progress, (London and New York: Anthem Press, 2010), hlm. 1 


\section{Pendahuluan}

"Siapa saja yang mengabaikan agama dalam analisisnya atas persoalanpersoalan kontemporer berarti mengambil risiko yang sangat besar."3 Agama merupakan sebuah fenomena sosial, dan karenanya ada pada proses timbal balik yang terus menerus serta hubungan interaktif dengan fenomena sosial lainnya. ${ }^{4}$ Konflik dan integrasi merupakan dinamika yang mengiringi agama. Saya akan menyarikan pemikiran tiga tokoh penting dalam studi sosiologis tentang agama, Karl Marx, Max Weber dan Emile Durkheim.

Pokok yang menjadi bahasan sosiologi Marx salah satunya adalah soal alienasi. Dalam "Economic and Philosophic Manuscripts of 1844", Marx menunjukkan bentuk keterasingan manusia yang disebabkan oleh pekerjaan (baca: ekonomi politik). Melalui tulisannya itu, Marx mengatakan kalau pekerjaan pada gilirannya menjadi komoditas, bahkan menjadi komoditas yang paling menyusahkan; penderitaan pekerja itu bertambah buruk bersamaan dengan bertambahnya kekuasaan dan jumlah produksinya. Hasil dari persaingan adalah terkumpulnya modal pada segelintir orang, dan mapannya monopoli dalam bentuknya yang lebih buruk. Pada akhirnya perbedaan antara pemilik modal dan tuan tanah, dan antara buruh pertanian dan pekerja industri pasti akan terlihat dan keseluruhan masyarakat terbagi menjadi dua kelas, yakni pemilik yang kaya (propertyowners) dan pekerja yang miskin (propertyless-workers). ${ }^{5}$

Bahasan tentang ekonomi menjadi sentrum dari pemikiran Marx. Dalam "The German Ideology", Marx merumuskan premis dasar bahwa bidang ekonomi menentukan bidang politik dan pemikiran manusia, bahwa bidang ekonomi ditentukan oleh pertentangan antara kelas-kelas pekerja dan kelas-kelas pemilik, bahwa pertentangan itu dipertajam oleh kemajuan teknik produksi, dan bahwa pertentangan itu akhirnya meledak dalam sebuah revolusi yang mengubah struktur kekuasaan di bidang ekonomi serta mengubah struktur kenegaraan dan gaya manusia berpikir. ${ }^{6}$

\footnotetext{
3 Peter L. Berger, "The Desecularization of the World: A Global Overview”, dalam Peter L. Berger (ed), The Desecularization of the World: Resurgent Religion and World Politics (Washington DC-Grand Rapids Michigan: Ethics and Public Policy Center-William B. Eerdmans Publishing Company, 1999), hlm. 18.

4 Ronald L. Johnstone, Religion in Society: Sociology of Religion, (New Jersey: Prentice Hall, 1992), Fourth Edition, hlm. 1.

${ }^{5}$ Robert C. Tucker (ed), The Marx-Engels Reader (London, New York: Norton Company, 1978), hlm. 70.

6Ibid.hlm, 147-200.
} 
Saat seorang buruh melakukan pekerjaan, Marx melihat kalau sang buruh itu jatuh lebih miskin dari apa yang ia hasilkan dan meningkatnya daya serta jangkauan barang tersebut. ${ }^{7}$ Barang yang dihasilkan pekerja merangkak jauh lebih mahal daripada dirinya. Peningkatan devaluasi kemanusiaan di satu sisi, dibarengi dengan meningkatnya nilai barang di sisi yang lain. Kata Marx, labor produce not only commodities; it produces itself and the worker as a commodity. ${ }^{8}$

Pada gilirannya, tindakan itu mengimplikasikan bahwa objek yang diproduksi buruh kini bertentangan dengan buruh itu sendiri; objek itu menjadi makhluk asing dan kekuatan yang bebas dari pembuatnya. ${ }^{9}$ Apa yang dihasilkan buruh adalah dirinya sendiri yang telah diwujudkan dalam bentuk objek dan kemudian berubah menjadi benda fisik; produk ini merupakan objektifikasi (objectification) buruh. ${ }^{10}$ Tindakan kerja pada saat yang sama, tidak lebih dari objektifikasinya. Tindakan kerja, oleh ekonomi politik dilihat sebagai pelemahan kerja, objektifikasi sebagai penghilangan dan sebagai perbudakan pada objek, dan apropriasi sebagai alienasi. ${ }^{11}$ Tindakan kerja benar-benar terlihat sebagai pelemahan, yakni ketika pekerja dilemahkan hingga menderita kelaparan. Objektifikasi terlihat sebagai penghilangan objek, yakni pekerja dicabut, bukan hanya dari esensi kehidupan, tetapi juga dari esensi pekerjaannya. Konsekuensi itu muncul dari fakta bahwa pekerja berhubungan dengan hasil kerjanya sebagaimana dengan objek yang asing. Semakin jelaslah bahwa semakin pekerja mengembangkan dirinya dalam kerja, semakin kuat objek yang diciptakannya yang berada dihadapannya, maka semakin miskinlah kehidupan batiniahnya dan semakin dia tidak menjadi dirinya sendiri. Hal yang sama sebenarnya juga berlaku pada agama. Semakin manusia mensifati dirinya dengan Tuhan, dia tidak mempunyai kehidupan dalam dirinya. ${ }^{12}$ Pekerjaan menyerahkan hidupnya pada objek, kemudian kehidupannya tidak lagi menjadi dirinya, tetapi milik objek. Kritik Marx terhadap agama (selain sebagai alienasi) bisa dilihat saat ia menjelaskan soal kesadaran (manusia). Manusia adalah produsen ide, konsepsi dan lainnya. Cara memahami manusia bukanlah berbicara dari apa yang dikatakan,

7Ibid,hlm. 71.

8 Ibid.

${ }^{9}$ Ibid.

10 Ibid.

${ }^{11}$ Ibid,hlm. 71-72.

12Ibid,hlm, 72. 
dimimpikan dan dipahami manusia, juga tidak berbicara dari apa yang ternarasikan, terpikirkan, terbayangkan dan terpahami manusia. Untuk sampai pada manusia, maka penting untuk melihat manusia nyata yang aktif dari kehidupan faktualnya.

Apa yang ada dalam pikiran manusia sebenarnya juga tak lain dari sublimasi dari proses kehidupan manusia, yang secara empiris dapat diverifikasi dan terikat dengan premis-premis material. Moralitas, agama, metafisika, semua ideologi dan bentuk kesadaran yang terikat, makanya tidak mempertahankan kemiripan independensinya. Kesemuanya itu tidak memiliki sejarah, perkembangan, tetapi manusialah yang mengembangkan produksi dan hubungan materialnya, mengubah, sepanjang eksistensi nyatanya, pemikiran dan produk-produk berpikirnya. Makna kehidupan yang paling hakiki diuraikan dalam satu frase yang cukup menarik bahwa "Hidup tidak ditentukan oleh kesadaran, tetapi kesadaran ditentukan oleh hidup" (life is not determined by consciousness, but consciousness by life). Dalam pendekatan pertama, titik awalnya adalah kesadaran yang dimiliki oleh individu-individu yang hidup, sedangkan dalam pendekatan yang kedua, titik awalnya adalah individu-individu itu sendiri yang hidup secara nyata, karena mereka berada dalam kehidupan aktual, sedangkan kesadaran dengan sendirinya semata-mata dianggap sebagai kesadaran mereka.

Pendekatan yang pertama, dengan menjadikan kesadaran sebagai titik awal, bagi Marx sama sekali tidak bisa dijadikan premis. Pendekatan hanya bisa dimulai dari premis nyata. Premis-premisnya adalah manusia, bukan isolasi fantastik atau definisi abstrak, yang berada dalam proses perkembangan yang aktual yang bisa dipahami secara empiris di bawah kondisi-kondisi tertentu. Inilah filosofi dari gagasan pokok materialisme Marx. Ia kemudian melanjutkan bahwa segera setelah proses kehidupan yang aktif ini dideskripsikan, sejarah tidak lagi menjadi sekadar koleksi fakta-fakta beku karena sejarah berada di tangan para empiris (tetapi mereka sendiri masih abstrak), atau menjadi sebuah aktivitas imajiner dari subjek-subjek yang imajiner juga ketika sejarah berada di tangan idealis. Inilah sebenarnya filosofi dari kritik Marx terhadap agama. Ia kemudian menggambarkan kritik terhadap agama adalah prasyarat terhadap seluruh kritik. ${ }^{13}$ Landasan kritisisme irreligious adalah; manusia menciptakan agama, bukan agama yang

${ }^{13}$ Ibid,hlm. 53 
menciptakan manusia. ${ }^{14}$ Marx konsisten dengan argumentasinya bahwa manusia adalah penggerak sejarah, termasuk dalam kaitannya dengan agama. Menurut Marx, agama adalah sebentuk kesadaran diri (self consciousness) dan harga diri (self esteem) manusia yang belum menemukan dirinya sendiri atau sudah kehilangan dirinya sendiri. ${ }^{15}$ Hanya saja perlu dimengerti bahwa manusia menginjakkan kakinya di bumi, dalam sebuah edaran sejarah. Manusia adalah dunia umat manusia; negara, masyarakat (state, society). Ia berada diantara masyarakat. Masyarakat itulah yang menghasilkan agama yang oleh Marx dianggap sebagai kesadaran dunia yang terbalik dimana agama merupakan teori umum tentang dunia tersebut. Marx kemudian menuturkan bahwa agama merupakan realisasi esensi manusia (human essence) yang penuh khayalan (fantasi) karena inti manusia itu belum memiliki realitas yang nyata. ${ }^{16}$ Bagi Andrew McKinnon, pernyataan ini merupakan gambaran agama seperti yang diungkapkan oleh Ludwig Feurbach. ${ }^{17}$ Maka, perjuangan melawan agama secara tidak langsung adalah perjuangan melawan sebuah dunia yang aroma spiritualnya adalah agama tersebut. Lalu Marx mengatakan,

"Religious suffering is, at one and the same time, the expression of real suffering and a protest against real suffering. Religion is the sigh of the oppressed creature, the heart of a heartless world, and the soul of soulless conditions. It is the opium of the people. The abolition of religion as the illusory happiness of the people is the demand for their real happiness. To call on them to give up their illusions about their condition is to call on them to give up a condition that requires illusion". 18

Agama sebagai "opium" kerapkali dijadikan sebagai "standar" untuk menggambarkan pikiran Marx soal agama. Daniel L. Pas tidak terlalu mementingkan

14 Ibid.

15 Ibid.

16 Ibid.

17 Andrew McKinnon, "Opium as Dialectics of Religion: Metaphor, Expression and Protest", dalam Warren S. Goldstein (ed), Marx, Critical Theory and Religion: A Critique of Rational Choice, (Boston: BRILL, 2006), hlm.20.

18 Kesengsaraan agamis merupakan ekspresi kesengsaraan nyata sekaligus merupakan protes terhadap kesengsaraan yang nyata tersebut. Agama adalah keluhan para makhluk tertindas, jantung-hati sebuah dunia tanpa hati, jiwa untuk keadaan tak berjiwa. Agama adalah candu rakyat... Menghapuskan agama sebagai kebahagiaan ilusioner untuk rakyat, berarti menuntut agar rakyat dibahagiakan dalam kenyataan. Maka, panggilan supaya mereka melepaskan ilusi tentang keadaan mereka adalah panggilan agar mereka melepaskan keadaan di mana ilusi itu diperlukan. Ibid. 
apakah Marx tahu kegunaan opium pada masanya itu atau tidak. ${ }^{19}$ Yang pasti, Marx tahu bahwa opium adalah narkotik dan halusinogenik yang dapat meringankan rasa sakit dan menciptakan fantasi-fantasi. Disitulah makna agama yang dapat meringankan beban bagi mereka yang membutuhkan, terutama orang-orang miskin. Berangkat dari kenyataan seperti itu, Marx memberi solusi dengan mengamini tawaran Ludwig Feurbach. Dalam "Theses on Feurbach," Marx mengatakan the philosophers have only interpreted the world, in various ways; the point, however, is to change it. ${ }^{20}$

Meski menyetujui komentar Feurbach soal upaya merubah dunia (tidak hanya menafsirkan), namun Marx mengkritik pendapat Feurbach soal agama. Marx menilai gagasan Feurbach tentang esensi agama itu sebagai suatu yang abstrak. Dalam "Theses of Feurbach," Marx menuturkan kalau Feurbach melebur hakekat keagamaan ke dalam hakekat kemanusiaan. Tetapi hakekat kemanusiaan bukanlah abstraksi yang terdapat pada satu-satu individu. Dalam kenyataannya, ia adalah keseluruhan dari hubungan-hubungan sosial. ${ }^{21}$ Berbeda dengan Feurbach yang menekankan pada abstraknya esensi manusia, Marx bergerak pada ranah yang lebih konkrit. Dengan memperluas makna "ekspresi", Marx menggarisbawahi pentingnya dimensi sosial dengan mengatakan bahwa agama adalah semangat dari mereka yang tak memiliki semangat dan hati dari situasi sosial yang tak berhati, dimana agama merupakan keluhan dan saksi terhadap penindasan. ${ }^{22}$

Pengertian Marx tentang agama telah bergerak dari percaturan teologi dan menjadikannya sebagai problem ekonomi dan politik. Selain itu, Marx menempatkan agama lebih konkret daripada Feurbach, dengan mengalamatkannya pada negara dan masyarakat, bukan esensi manusia. Kaitannya dengan persoalan ekonomi, Marx menunjukkan paralelitasnya dengan agama. Keduanya ditandai oleh alienasi. ${ }^{23}$ Walaupun demikian, Marx juga menyoroti hubungan antara kehidupan material dan spiritual yang saling mempengaruhi. Kehidupan di bidang ekonomi akan merubah kehidupan spiritual. ${ }^{24}$ Pada akhir abad pertengahan memang kita menyaksikan hadirnya kapitalisme dan pergeseran dari Katolikisme ke Protestantisme. Hanya saja pertanyaannya kemudian,

${ }^{19}$ Daniel L. Pas, Eight Theories of Religion (New York: Oxford University Press, 2006),hlm. 135.

${ }^{20}$ Robert C. Tucker (ed), The Marx-Engels Reader.hlm. 145.

${ }^{21}$ Ibid.

${ }^{22}$ Andrew McKinnon, "Opium as Dialectics of Religion.hlm, 22.

${ }^{23}$ Daniel L. Pas, Eight Theories of Religion. hlm.134.

${ }^{24}$ Ibid.hlm, 141. 
apakah faktor ekonomi menjadi satu-satunya agen perubahan tersebut? Atau bisa jadi yang ada dalam kenyataan adalah hal sebaliknya, dimana nilai agama yang merubah kehidupan ekonomi? Pertanyaan terakhir ini menggiring kita pada pemikiran tokoh Jerman yang lahir dua dasawarsa setelah kematian Marx yakni, Max Weber.

Fokus utama dari tulisan-tulisan Max Weber dalam wilayah agama, dibentangkan hingga masalah organisasi dan proses ekonomi, sistem politik organisasi formal, dan hukum. Ketika dia berbicara tentang agama, Weber tidak menuturkan agama "as such" seperti halnya para teolog atau sejarawan gereja mengupasnya, tetapi hubungan antara ide-ide keagamaan dan komitmen serta aspek lain dari kehidupan manusia terutama karakteristik manusia dalam sebuah masyarakat. Konsentrasi Weber adalah mengkhususkan diri pada apa yang disebut sebagai sosiologi agama. Weber menampilkan fase baru dalam memahami hubungan antara aspek keagamaan dan aspek lain dari perilaku manusia.

Soal mendefinisikan agama, bisa dikatakan bahwa Weber adalah orang yang gagal melakukannya. Setidak-tidaknya sebuah catatan sistematika tentang apa yang akan dilakukan untuk sampai pada pembuatan definisi agama, Weber tidak berhasil memformulasikan hal tersebut. Weber mengatakan, mendefinisikan agama, mengatakan apa itu agama, tidaklah mungkin dimulai dari awal penyajian. Definisi dapat dilakukan hanya pada kesimpulan dari kajian ini. "Esensi sebuah agama bukanlah perhatian kami, tugas kami adalah mempelajari kondisi-kondisi dan pengaruh jenis tertentu dari perilaku sosial," kata Weber. ${ }^{25}$

Dengan begitu, maka secara apa adanya, Weber mengatakan bahwa perilaku sosial yang dibahasnya dalam sosiologi agamanya akan dimasukkan dengan istilah agama. Karenanya, kita juga harus menerima pandangan implisitnya tentang Budhisme, Islam, Judaisme dan Kristen yang semuanya adalah agama. Menurut Weber dimensi eksternal dari perilaku keagamaan itu berbeda-beda dan bahwa pemahaman terhadap perilaku ini hanya dapat dicapai dari sudut pandang pengalaman-pengalaman subjektif, ide dan maksud-maksud dari individu yang berkaitan atau singkatnya, dari sudut pandang

25 Guenter Roth and Claus Wittich (ed), Max Weber: Economy and Society, vol.I (Los Angeles: University of California Press, 1978), hlm. 399. 
“makna” perilaku keberagamaan. ${ }^{26}$ Bentuk yang paling dasar dari perilaku manusia, termotivasi oleh faktor agama atau magis berorientasi ke dunia ini. ${ }^{27}$ Bagi Weber, baik tindakan maupun pikiran tentang agama ataupun magis tidak bisa dipisahkan dari maksud tertentu, terutama karena dari awal bahkan hingga akhir tindakan agama atau magis didominasi persoalan ekonomi. ${ }^{28}$

Berbeda halnya dengan Marx yang menyebut ekonomi berperan dalam mengubah superstruktur termasuk di dalamnya agama, Weber justru berpendapat sebaliknya. Weber menjabarkan Etika Protestan serta relasinya dengan semangat kapitalisme. ${ }^{29}$ Weber menunjukkan bahwa perkembangan di bidang ekonomi, terutama dengan munculnya semangat kapitalisme modern di dunia barat, telah dipandang sebagai sesuatu yang tidak berdiri sendiri. ${ }^{30}$ Kapitalisme modern di dunia barat, menurut Weber timbul sebagai akumulasi dari kekuatan sosial, politik dan ekonomi serta agama yang berakar jauh di dalam sejarah Eropa.

Kapitalisme, sebagai suatu sistem perekonomian, yang terletak pada suatu organisasi dari para penerima upah bebas secara legal, dengan suatu tujuan untuk mendapatkan keuntungan uang, dari para pemilik modal dan agen-agennya, dan membuat tanda-tanda dalam setiap aspek masyarakat, merupakan suatu fenomena modern. Weber menunjukan salah satu elemen fundamental dari spirit kapitalisme modern dan seluruh budaya modern adalah tindakan rasional yang didasarkan pada panggilan (calling) yang lahir dari semangat asekese Kristen. ${ }^{31}$ Weber disini menyebut soal calling (panggilan). Gejolak reformasi telah berhasil memisahkan dualisme moral yang berlaku universal dan kepatuhan yang sangat keras. ${ }^{32}$ Calvin berusaha menghindari kesulitan bagaimana memahami manusia dan anugerah Tuhan. Calvinisme mengutuk kenikmatan, tetapi tidak mengijinkan pelarian dari keduniaan dan menganggap bekerja dengan orang-orang lain

\footnotetext{
26 Ibid.

27 Ibid.

${ }^{28}$ Ibid.hlm, 400.

${ }^{29}$ Max Weber, The Protestant Ethic and the Spirit of Capitalism (New York: Charles Scribner's Sons,

${ }^{30}$ Ibid.

31 Ibid.hlm, 180

${ }^{32}$ Stanislav Andreski, Max Weber on Capitalism, Bureaucracy and Religion, terj. Hartono, "Max Weber: Kapitalisme, Birokrasi dan Agama" (Yogyakarta: Tiara Wacana, 1989),hlm. 129.
} 1976). 
dibawah sebuah disiplin rasional sebagai kewajiban religius seseorang. ${ }^{33}$ Bagi kaum Calvinis, suatu panggilan bukanlah suatu kondisi sejak manusia dilahirkan, tetapi merupakan usaha manusia yang sangat sulit dan berat yang telah dipilih oleh manusia sendiri dan yang telah dicari lewat rasa tanggungjawabnya. Disinilah kemudian Weber menyebut kata "vokasi" atau vocation. ${ }^{34}$ Vokasi bisa bermakna bahwa bekerja bukanlah semata-mata sarana atau alat ekonomi, tetapi ibadah. ${ }^{35}$

Di bagian awal buku The Protestant Ethic, Weber menunjukkan gejala kapitalisme dengan membandingkan antara tradisi Katolik dan Protestan. Dengan melihat data statistik di negara Eropa, Weber mengatakan bahwa keanekaragaman pemeluk agama di Jerman, mendorong media massa dan literatur Katolik serta diskusi-diskusi di kongres Katolik di Jerman untuk menghadapi kenyataan bahwa para pemimpin bisnis dan pemilik modal maupun para karyawan perusahaan yang memiliki kemampuan tinggi ataupun staf terdidik, baik secara teknis maupun komersil ternyata kebanyakan adalah orang Protestan. ${ }^{36}$

Disitu terlihat partisipasi relatif yang lebih besar dari orang-orang Protestan dalam hal kepemilikan modal, manajemen dan dalam tingkat pekerjaan karyawan yang lebih tinggi pada industri-industri modern dan perusahaan-perusahaan komersial yang besar mungkin sebagian bisa dijelaskan dalam aspek kondisi-kondisi historis, yakni satu aspek yang menarik perhatian kita ke masa silam dan pada saat ketika aliansi agama bukanlah sebab dari kondisi perekonomian, namun pada saat tertentu nampak seperti akibat dari kondisi-kondisi itu. Partisipasi dalam fungsi-fungsi perekonomian seperti tersebut di atas biasanya melibatkan beberapa kepemilikan modal sebelumnya dan pada umumnya melibatkan juga biaya pendidikan yang mahal dan seringkali pula melibatkan keduanya sekaligus. Beberapa bagian dari Kekaisaran tua yang dalam bidang ekonomi tumbuh paling pesat dan didukung oleh sumber-sumber alam dan situasi, khususnya mayoritas di kota-kota kaya mengenal Protestantisme pada abad 16. Situasi inilah yang mendorong orang Protestan bahkan sampai sekarang, dalam perjuangan mereka untuk memperoleh kehidupan ekonomi yang lebih baik. Dengan menyandarkan pada uraian Martin

33Ibid.hlm, 130.

34 Ibid. Lihat pada bagian politics as vocation dan science as vocation. H.H. Gerth dan Charles Wright Mills, From Max Weber: Essays in Sociology (New York: Oxford University Press, 1946), hlm. 77-128.

35 Ibid.

${ }^{36}$ Max Weber, The Protestant Ethic.hlm. 35. 
Offenbacher, Weber membuat kesimpulan tentang perbedaan-perbedaan yang ada dalam tradisi Katolik dan Protestan itu kaitannya dengan dunia ekonomi. "Orang-orang Katolik biasanya lebih tenang, mempunyai keinginan yang lebih kecil untuk memperoleh sesuatu; mereka lebih menyukai kehidupan dengan kenyamanan yang terjamin walau hanya dengan mendapat penghasilan yang lebih kecil daripada memilih kehidupan yang dipenuhi risiko dan kesenangan walau jenis pekerjaan itu memberi banyak kesempatan untuk mendapatkan kehormatan dan kekayaan."37 Jika dihadapkan pada pilihan "makan enak atau tidur nyenyak" (eat well or sleep well), maka kata Weber, Protestant prefers to eat well, the Catholic to sleep undisturbed. ${ }^{38}$

Proses rasionalisasi hadir dari cita-cita kapitalisme dan karenanya agama yang ajaran-ajarannya teratur dan tersusun rapi juga berusaha untuk melembagakan sistem kepercayaan juga sistem nilai yang lain, termasuk bidang ekonomi, untuk memberikan rasa puas dan aman kepada para pemeluknya. ${ }^{39}$ Agama adalah merupakan penjelasan rasional sekaligus mengatur nilai-nilai serta kepercayaan teologis. Diantara bangunan kepercayaan inilah dibangun pemikiran-pemikiran rasional.

Dari sini dapat dimengerti bahwa proses rasionalisasi yang disebut Weber juga berasal dari agama itu sendiri, disamping perkembangan daya nalar manusia yang dengan cepat dapat mengikuti proses tersebut. Daya nalar itu baik dalam arti formal sehubungan dengan konsistensinya (kemantapan dalam bertindak) dan sifat sistematikanya maupuan dalam arti substansi (kokoh) dalam menyisihkan hal-hal yang tidak rasional dan mengandung fantasi atau mitos. Lepas dari berbagai kritik yang muncul terhadap tesisnya, Weber menunjukan bahwa dalam sistem ekonomi tersebut terlihat perkembangan teologi rasional. ${ }^{40}$ Perkembangan ini nampak dalam masyarakat Barat. Dengan demikian, menurut Weber, ciri dari kegiatan perekonomian yang bersifat kapitalistis adalah rasionalitas yang didasarkan kepada perhitungan-perhitungan yang cermat yang disusun secara sistematis dan sederhana berdasarkan situasi ekonomi yang diharapkan.

${ }^{37}$ Ibid.hlm. 40-41.

38Ibid.hlm. 41.

${ }^{39}$ Ajat Sudrajat, Etika Protestan dan Kapitalisme Barat Relevansinya dengan Islam Indonesia (Jakarta: Bumi Aksara, 1994), hlm. 37

40 Richard L. Means, "Weber's Thesis of the Protestant Ethic: The Ambiguities of Received Doctrine", The Journal of Religion, Vol. 45, No. 1. (Jan., 1965), 1-11 dan Bryan S. Turner, "Islam, Capitalism and the Weber Theses", The British Journal of Sociology, Vol. 25, No. 2. (Jun., 1974), hlm. 230-243. 
Sementara, studi Emile Durkheim menunjukan bagaimana hubungan antara agama dan integrasi sosial. Pandangan Durkheim tentang agama terpusat pada klaimnya bahwa ide tentang masyarakat menjadi jiwa dari agama. ${ }^{41}$ Sumber agama adalah masyarakat itu sendiri yang akan menilai sesuatu itu bersifat sacral atau profan. Durkheim menemukan karakteristik paling mendasar dari setiap kepercayaan agama bukanlah terletak pada elemen-elemen "supernatural", melainkan terletak pada konsep tentang "yang sakral" atau thesacred, dimana keduanya yaitu supernatural dan yang sakral, memiliki perbedaan yang mendasar.

Kesimpulan demikian ia tandaskan dalam magnum opusnya, The Elementary Forms of Religious Life. ${ }^{42}$ Sesuai dengan judul bukunya, apa yang ditawarkan oleh Durkheim dalam karya tebal itu antara lain tentang bentuk dasar dari agama. Atau Durkheim dalam karya tersebut, hendak melihat tentang struktur dasar dari kepercayaan yang kemudian membentuk apa yang kita sebut sebagai agama. Terkait dengan masyarakat, agama kata Durkheim, sebagaimana dikutip Swidler dan Mojzes, telah melahirkan banyak sesuatu yang esensial dalam masyarakat. ${ }^{43}$ Kita dapat memantapkan fakta bahwa kategori-kategori fundamental dari pemikiran dan konsekuensi pengatahuan adalah asal-usul agama. Dalam perkembangannya, banyak institusi sosial yang besar, lahir dalam agama. ${ }^{44}$

Agama dalam bahasan Durkheim tidak bisa dilepaskan dari tema moral dan masyarakat, baik fungsi maupun hakikatnya. ${ }^{45}$ Dalam masyarakat, terkandung apa yang disebut solidaritas yang merupakan domain sosiologi. ${ }^{46}$ Solidaritas merupakan fakta sosial yang hanya bisa diketahui melalui efek sosialnya. Menurut Durkheim, di antara semua unsur peradaban ilmu pengetahuan adalah satu-satunya untuk menganggap, dalam kondisi tertentu, sebuah karakter moral. ${ }^{47}$ Akibatnya, karena peradaban terdiri dari apaapa yang menampilkan ini kriteria moralitas, secara moral netral. Sehingga jika peran

\footnotetext{
${ }^{41}$ Daniel L. Pas, Eight Theories of Religion.hlm. 85.

42 Emile Durkheim, The Elementary Forms of Religious Life, (New York: The Free Press, 1995).

43 Leonard Swidler dan Paul Mojzes, The Study of Religion in an Age of Global Dialogue (Philadelphia: Temple University Press, 2000),hlm. 1.

44 Ibid.

45 Emile Durkheim, The Division of Labor in Society (New York: The Free Press, 1984).

46Ibid.hlm, 27.

47 Ibid.hlm, 13.
} 
pembagian kerja yang semata-mata untuk membuat peradaban mungkin, akan membangun netralitas moral yang sama. ${ }^{48}$

Untuk mengetahui bentuk dasar dari agama, Durkheim memilih melakukan analisis terhadap agama-agama primitif, ketimbang agama-agama modern. Sistem keyakinan yang primitif dapat ditemukan pada masyarakat sederhana dan dapat dengan mudah dijelaskan. Atas alasan tersebut, Durkheim kemudian memilih Suku Arunta masyarakat Aborigin di Australia sebagai sample penelitiannya terhadap agama untuk dapat memberikan pengetahuan tentang apa itu agama. ${ }^{49}$ Masyarakat primitif seperti Aborigin, dapat lebih mudah dipahami konteks keyakinannya dibanding masyarakat modern yang kompleks. Mereka (baca: masyarakat primitif) memenuhi kebutuhan yang sama, memainkan peran yang sama, dan bertolak dari sebab yang sama. Oleh karenanya mereka dapat menjelaskan karakter dasar dari kehidupan keagamaan. ${ }^{50}$

Studinya tentang agama, kata Durkheim merupakan langkah untuk mengangkat persoalan lama tentang asal usul agama, but under new conditions. ${ }^{51}$ Pada dasarnya, menurut Durkheim tidak ada agama yang salah. Semua agama benar menurut fashion-nya masing-masing. Semuanya memenuhi kondisi tertentu dari manusia, meskipun dengan jalan yang berbeda. ${ }^{52}$ Wajar kalau Durkheim sendiri tidak tertarik dengan status epistemologi agama, yakni pertanyaan apakah keyakinan agama itu benar atau salah. Penelitiannya terhadap masyarakat primitif, sama sekali bukan berarti gagasan itu menurunkan nilai agama pada umumnya, karena agama-agama tersebut tidak kurang terhormat dibandingkan agama lainnya. ${ }^{53}$ Agama-agama, kata Durkheim merespon kebutuhan yang sama, memainkan peran yang sama, bergantung pada sebab yang sama; ia juga dapat berfungsi untuk menunjukkan sifat kehidupan keagamaan dengan baik.

Skema pemikiran Marx, Weber dan Durkheim dalam diskursus agama merupakan konseptualisasi gagasan mengenai hubungannya dengan masalah sosial. Marx melihat agama sangat berkaitan dengan masalah ekonomi sebagai basisnya. Sementara agama itu sendiri oleh Marx ditempatkan sebagai bangunan atas, alias superstruktur. Marx

\footnotetext{
48Ibid.,hlm. 15.

49 Emile Durkheim, The Elementary Forms. . .21

${ }^{50}$ Ibid.,hlm. 3.

51 Ibid.,hlm. 7.

${ }^{52}$ Ibid.,hlm 2.

53Ibid.,hlm. 3.
} 
menyadari bahwa baik ekonomi maupun agama berperan untuk menciptakan alienasi. Kaitan antara basis dan superstruktur bisa dijelaskan dengan rumusan sederhana, bahwa perubahan struktur ekonomi yang ada di bawah, akan berperan besar dalam mengubah bangunan atasnya. Tentunya kritik ekonomi itu berada pada kendali masyarakat dan negara, bukan individu. Disinilah ia mengkritik Feurbach.

Berbeda dengan Marx yang menyebut ekonomi sebagai basis yang dapat merubah pandangan agama, Weber justru melihat sebaliknya. Etika Protestan, justru berperan besar dalam merubah tatanan ekonomi. Kapitalisme terbangun melalui rasionalisasi dan berjalan dengan sangat baik di dunia barat. Sementara di dunia timur, kapitalisme agak sulit berkembang seperti halnya di Barat. Tentu saja kenyataan ini dilatari oleh perbedaan agama yang menjadi dasar kehidupan masyarakat di sana. Dengan memunculkan tesis bahwa prilaku agama sangat mempengaruhi ekonomi, maka Weber dengan tegas mengkritik determinisme ekonominya Marx. Weber meyakini bahwa agama menjadi sumber terciptanya perubahan sosial.

Sementara Durkheim menunjukan semangat fungsionalismenya dalam membahas agama. Durkheim memunculkan masyarakat dalam konteks solidaritas sosial, kohesi sosial dan integrasi sosialnya. Karena itu, Durkheim seringkali menyebut agama sebagai sebuah fakta sosial, bukan fakta individual. Ia harus dilihat sebagai persoalan kelompok. Durkheim menunjukan hal ini ketika membahas fenomena bunuh diri dalam karyanya, "Suicide". Bunuh diri, terutama yang bersifat egoistik, bagi Durkheim hanya bisa dilihat semata-mata sebagai persoalan sosiologis, bukan psikologis. Kata Durkheim, "the conclusion from all these facts is that the social suicide-rate can be explained only sociologically". 54 Studinya tentang masyarakat Arunta memperlihatkan bahwa ada simbol yang dapat mempersatukan anggota masyarakat ke dalam sebuah kelompok. Disini, peran totemisme perlu diperhatikan. Ia menjadi simbol terintegrasi individuindividu itu ke dalam satu kelompok yang secara bersama-sama memiliki "Yang Sakral".

Marx Weber dan Durkheim sama-sama melihat agama dalam kaitannya dengan kehidupan sosial. Ketiganya meyakini bahwa salah satu dari dua elemen tersebut berpengaruh satu terhadap lainnya. Marx dan Weber bersepakat bahwa klaim kausal yang terpenting dari agama adalah persoalan ekonomi. Sementara Durkheim tidak terlalu

${ }^{54}$ Emile Durkheim, Suicide: A Study in Sociology (New York: Free Press, 1968), 299. 
mempersoalkan aspek yang khas dari kehidupan manusia itu, apakah ekonomi, politik atau yang lain. Pendek kata, yang paling penting menurut Durkheim adalah sistem sosial dalam masyarakat itu sendiri.

Durkheim dan Weber bersepakat bahwa agama memiliki fungsi dalam kehidupan masyarakat. Durkheim melihat agama sebagai memiliki peran dalam mengintegrasikan sistem sosial. Agama atau etika keagamaan juga berperan dalam mempengaruhi atau merubah sistem ekonomi (kapitalisme) seperti kata Weber. Disinilah Marx justru berpendapat sebaliknya bahwa agama merupakan variabel terpengaruh, sementara yang menjadi variabel bebasnya adalah ekonomi. Agama bagi Marx justru hanya menjadi tempat pelarian manusia yang tidak berdaya menghadapi kenyataan hidup.

\section{Pembahasan}

Masa kondisi apa seorang tokoh agama memilih jalan kekerasan? Dalam kondisi apa tokoh agama menolak kekerasan dan mempertanyakan komitmen kelompok ekstrimis tentang kekerasan seagai kewajiban suci? Dalam kondisi apa tokoh agama yang anti kekerasan bisa menjadi agen perdamaian? Tiga pertanyaan tersebut diajukan oleh R. Scott Appleby dalam bukunya The Ambivalence of the Sacred. ${ }^{55}$ Abad pertengahan, agama digambarkan sebagai "motivasi yang menyala-nyala, sesuatu yang mengilhami pemujaan secara fanatik dan menimbulkan rasa kebencian yang mendalam." Situasi demikian terjadi antara tahun 1560-an hingga 1650-an. ${ }^{56}$ Gereja Katolik menolak Revolusi Perancis di akhir abad 18 dan mengutuk pernyataan yang dilahirkannya, liberalism, demokrasi dan nasionalisme sekuler pada abad 19. Agama, baik di dalam maupun luar negeri, dicampuradukkan dengan tujuan untuk menjajah atau ekspansi kolonial bangsa Inggris dan Kerajaan Perancis, dimana diantara mereka menguasai Kanada, Australia, Selandia Baru, menjajah Afrika Utara dan Selatan serta kepulauan Karibia, India dan sebagian besar Afrika, Timur Tengah dan Asia Timur.

Kekerasan yang diilhami oleh agama jelaslah bukan sesuatu yang luar biasa, dan ada sepanjang sejarah agama itu sendiri. Abdelwahab Meddeb, Profesor comparative literature di University of Paris X-Nanterre, Perancis mengatakan, ada beberapa penyakit

55 R. Scott Appleby, The Ambivalence of the Sacred: Religion, Violence and Reconciliation, (Rowman and Littlefield Publishers, 2000).

56Ibid., hlm. 2. 
Islam. Antara lain adalah penolakan terhadap demokrasi, sekularisasi, nation-state. Ini ditolak karena berasal dari barat dan illegitimate.57 Wahabisme merupakan, kata Meddeb adalah salah satu "penyakit Islam" itu. Sasaran dari semua bentuk Wahabisme ini dimaksudkan agar seseorang lupa akan tubuh, objek, jarak, keindahan; pengaburan ini berarti pemaksaan untuk membuat a generalized amnesia, salah satu gejala penyakit yang melanda umat Islam. Penyakit ini bisa dilihat dalam banyak wilayah dan perilaku yang berbeda dalam pelbagai strata masyarakat. Meskipun demikian, Meddeb mengatakan bahwa ia tidak merasa bingung dengan penyakit-penyakit ini. "The sickness of Islam, it has existed throughout history. It exist now”, begitu kata Meddeb, tegas. Meski agama kerap jadi inspirasi kekerasan, tapi di sisi lain juga berfungsi sebagai obat. "Religion is indeed powerful medicine; it should be administered prudently, selectively and deliberately," kata Appleby.58 Sekarang, kita bisa menjawab pertanyaan yang diajukan Appleby di atas. Kondisi seperti apa yang bisa membuat seseorang menjadi ekstrimis atau sebaliknya.

Tradisi agama secara internal sesungguhnya plural, cair, berkembang dan responsif terhadap interpretasi baru yang dibuat oleh para pemimin agama, serta mampu membentuk individu, gerakan sosial dan komunitas yang mempraktekan dan mempromosikan toleransi dan anti kekerasan satu dengan lainnya.59 Kekerasan atas nama agama terjadi ketika pemimpin ekstrim dalam reaksinya terhadap ketidakadilan dalam struktur lingkungan masyarakat, berhasil menggunakan argumen agama dalam memobilisasi aktor-aktor agama untuk membalas kepada musuh-musuhnya. Sementara perdamaian umat beragama akan tercipta ketika militansi keberagamaan didedikasikan untuk teknis keterampilan anti kekerasan dan kemampuan professional dalam mencegah dan memberi peringatan dini, mediasi dan konsiliasi, serta elemen lain dalam transformasi konflik.

Sekarang kita masuk dalam dinamka kehidupan keberagamaan masyarakat Indonesia. pertanyaan pokokny, bagaimana kita memahami dan menjelaskan begitu merebaknya fenomena kekerasan serta bangkitnya konservatisme di Indonesia?

\footnotetext{
${ }^{57}$ Abdelwahab Meddeb, The Malady of Islam, Basic Books, (New York: 2003), hlm. 103.

58 R. Scott Appleby, 8.

${ }^{59}$ Ibid., hlm. 281.
} 
Ada dua penjelasan yang biasa digunakan untuk menyimak fenomena (pinjam istilahnya Martin van Bruinessen), conservative turn (belok ke arah konservatif) di Indonesia. Pertama, apa yang terjadi di sekitaran kita ini merupakan bagian dari situasi global yang memang mengarah pada kecenderungan konservatif. Salah satu peristiwa yang kerap dijadikan contoh adalah terpilihnya Donald Trump sebagai presiden Amerika Serikat. Bom bunuh diri di Manchester, Inggris serta serangan kelompok Maute di Kota Marawi, Filipina adalah dua situasi teranyar yang menggambarkan betapa kekerasan adalah fenomena yang mengglobal. Sederhana, pendulum sedang bergerak ke arah konservatif, tidak hanya di Indonesia, tetapi juga di belahan dunia lainnya.

Argumen kedua mengatakan bahwa arus konservatisme keagamaan di Indonesia merupakan fenomena momentual yang sesungguhnya diawali sejak era reformasi. Gejala konservatisme adalah situasi yang terfasilitasi melalui berbagai kesempatan. Ada media massa, media sosial, rumah ibadah, sekolah dan ruang publik lain yang kerap menjadi sarana untuk diseminasi ide-ide konservatif. Karenanya, jika akhir-akhir ini kita menemukan gejala yang semakin menguat, maka hal tersebut sesungguhnya bukanlah sesuatu yang betul-betul baru terjadi.

Memang tidak bisa dipungkiri kalau dinamika sosial sebuah wilayah tidak bisa benar-benar independen dan tak terkait dengan area lain. Apa yang terjadi di Timur Tengah dan Marawi misalnya menunjukkan hal ini. Secara ide, banyak individu atau kelompok militan di Indonesia yang mengamini gerakan-gerakan Islamic State di Syiria dan Irak. Beberapa diantaranya turut berperang dan terjun disana. Yang cukup kentara tentu di Marawi. Bahkan pemerintah Indonesia sudah bersiap di wilayah Sulawesi Utara karena akan sangat besar kemungkinan kelompok Maute akan menggunakan jalur laut ketika mereka terdesak setelah Presiden Filipina, Rodrigo Duterte mengumumkan darurat perang di Mindanao.

Sekali lagi, hal ini menunjukkan kalau berbicara tentang Indonesia dan hanya melihatnya sebagai gejala nasional semata, seolah menutup mata terhadap kompleksitas situasi di level global. Bom di Kampung Melayu, juga tidak bisa dijelaskan semata-mata sebagai fenomena yang khas dan hanya terjadi di Indonesia, karena pada waktu yang hampir bersamaan, di belahan lain, kekerasan dengan motivasi yang kurang lebih sama tengah berlangsung. 
Hanya saja, memberi penjelasan dengan cara menautkan persoalan "disini" dengan situasi "disana” juga tak sepenuhnya membantu. Bahwa ada ide keagamaan trans nasional yang melampaui batas-batas teritorialitas itu tak bisa dinafikan, namun bagaimana ide tersebut disemai, ditumbuhkembangkan serta diseminasikan, memiliki langgam yang tidak sama.

Tantangan yang dihadapi oleh kelompok-kelompok konservatif juga tak sama. Di Indonesia misalnya, kelompok radikal tidak hanya berhadapan dengan negara dan aparatusnya, tetapi juga kelompok muslim moderat yang sesungguhnya adalah mayoritas. Situasi di Filipina menunjukkan situasi yang berbeda dengan Indonesia dari sisi ini. Benigno Aquino, presiden sebelum Duterte berupaya untuk mempromosikan dialog dalam mencari solusi atas persoalan di selatan, hal yang tidak lagi banyak dilakukan oleh Duterte. Sikap Duterte tersebut semakin menebalkan keyakinan bagi kelompok-kelompok muslim radikal di selatan kalau mereka tak akan pernah mendapatkan perlakuan yang adil dari Manila. Situasi menjadi bertambah pelik karena memang ada beberapa kelompok di Filipina yang berafiliasi ataupun bersimpati dengan Islamic State, selain Maute, seperti Ansar Khalifa, Bangsamoro Islamic Freedom Fighters (BIFF) dan Moro Islamic Liberation Front (MILF).

Persoalan ideologi memang tak bisa dinafikan dalam fragmen kebangkitan politik identitas di belahan dunia manapun. Seorang teman bercerita tentang adiknya yang bersama suami dan anak-anaknya, pergi ke Syria untuk "jihad." Tidak ada persoalan ekonomi yang mendera mereka. Kehidupannya sungguh harmonis. Pilihannya tersebut murni karena insentif kerajaan surga yang akan diterimanya kelak jika mereka "syahid." Ini adalah kasus yang menunjukkan bahwa memang ada dorongan yang bersifat keagamaan dan atas alasan itulah mereka melakukan tindakan-tindakan kekerasan.

Tetapi, itu bukanlah satu-satunya penjelasan tentang bagaimana conservative turn terjadi. Saya ingin mengambil Filipina sebagai contoh lagi. Telah menjadi rahasia umum kalau Amerika Serikat dan Cina sedang berebut pengaruh di Filipina. Mereka berjuang untuk melakukan kontrol di kawasan Laut Cina Selatan yang menjadi sengketa. Tak hanya itu, Trump, seperti dilansir The Guardian (29/5), memuji ketegasan Duterte dalam menghadapi kelompok radikal dan berencana mengundangnya ke Gedung Putih. Cina, Jepang dan Rusia juga tengah berusaha untuk melakukan hal yang sama. Sementara 
negara-negara maju tengah berupaya mendapatkan keuntungan geopolitik, terorisme dan kekerasan terus berlangsung di Mindanao.

Saya selalu meyakini bahwa conservative turn adalah fenomena yang kompleks. Tak semata berhenti sebagai masalah ideologi saja, tapi lebih rumit dari itu, ia menggambarkan sebuah situasi dimana didalamnya ada kelindan dengan masalah ketidakadilan ekonomi dan politik.

Karena ada perbedaan konteks, maka strategi yang digunakan dalam menanggulanginya juga berbeda. Di Indonesia, Presiden Joko Widodo, melakukan strategi ganda; selain tentu saja memperketat barikade kepolisian dan militer, penguatan kelompok moderat Islam adalah cara kultural yang terus ditempuh karena memang elemen ini sokoguru utama keislaman di Indonesia.

\section{Penutup}

1. Agama sebagai penyumbang konsep kasih sayang, kedamaian, serta mengakomodir pemikiran - pemikiran yang humanis, logis dan profan.

2. Agama bukan alat atau legitimasi sekelompok orang untuk menghancurkan kelompok lain karena perbedaan pandangan, serta perbedaan kepentingan.

3. Agama dan negara merupakan hal kontradiktif. Agama bersifat sakral transedental, sementara negara bersifat formal struktural. Namun adanya negara memungkinkan orang beragama dapat tumbuh didalamnya.

4. NKRI secara tegas mengakui serta melindungi para pemeluk agama dalam menjalankan keyakinannya tanpa ada paksaan dan larangan. Bahkan penguatan kelompok moderat Islam di Indonesia sebagai upaya kultural dalam rangka melestarikan nilai-nilai keislaman di Indonesia. 


\section{DAFTAR PUSTAKA}

Andreski, Stanislav, Max Weber on Capitalism, Bureaucracy and Religion, terj. Hartono, "Max Weber: Kapitalisme, Birokrasi dan Agama" Yogyakarta: Tiara Wacana, 1989

Appleby, R. Scott, The Ambivalence of the Sacred: Religion, Violence and Reconciliation, Rowman and Littlefield Publishers, 2000.

Berger, Peter L., dan Gordon Redding (ed), The Hidden Form of Capital: Spiritual Inf luences in Societal Progress, London and New York: Anthem Press, 2010.

Berger, Peter L., "The Desecularization of the World: A Global Overview", dalam Peter L. Berger (ed), The Desecularization of the World: Resurgent Religion and World Politics Washington DC-Grand Rapids Michigan: Ethics and Public Policy Center-William B. Eerdmans Publishing Company, 1999

Durkheim, Emile, Suicide: A Study in Sociology, New York: Free Press, 1968

Durkheim, Emile, The Division of Labor in Society, New York: The Free Press, 1984

Durkheim, Emile, The Elementary Forms of Religious Life, New York: The Free Press, 1995

Gerth, H.H. dan Charles Wright Mills, From Max Weber: Essays in Sociology, New York: Oxford University Press, 1946

Johnstone, Ronald L., Religion in Society: Sociology of Religion, New Jersey: Prentice Hall, 1992

McKinnon, Andrew, "Opium as Dialectics of Religion: Metaphor, Expression and Protest", dalam Warren S. Goldstein (ed), Marx, Critical Theory and Religion: A Critique of Rational Choice, (Boston: BRILL, 2006

Means, Richard L., "Weber's Thesis of the Protestant Ethic: The Ambiguities of Received Doctrine", The Journal of Religion, Vol. 45, No. 1. Jan., 1965

Meddeb, Abdelwahab, The Malady of Islam, Basic Books, New York: 2003.

Pas, Daniel L., Eight Theories of Religion, New York: Oxford University Press, 2006

Roth, Guenter and Claus Wittich (ed), Max Weber: Economy and Society, vol.I Los Angeles: University of California Press, 1978

Sudrajat, Ajat, Etika Protestan dan Kapitalisme Barat Relevansinya dengan Islam Indonesia Jakarta: Bumi Aksara, 1994 
Swidler, Leonard dan Paul Mojzes, The Study of Religion in an Age of Global Dialogue (Philadelphia: Temple University Press, 2000

Tucker, Robert C. (ed), The Marx-Engels Reader (London, New York: Norton Company, 1978

Turner, Bryan S., "Islam, Capitalism and the Weber Theses", The British Journal of Sociology, Vol. 25, No. 2. Jun., 1974

Weber, Max, The Protestant Ethic and the Spirit of Capitalism New York: Charles Scribner's Sons, 1976 